Egyptian Journal of Aquatic Biology \& Fisheries

Zoology Department, Faculty of Science,

Ain Shams University, Cairo, Egypt.

ISSN 1110 - 6131 Vol. 22(3): 37- 54 (2018)

ejabf.journals.ekb.eg

\title{
Morphological re-description and molecular characterization of Heterocypris salina (Brady, 1868), a new recorded ostracod species in Egypt.
}

\author{
Fawzia S. Ali ${ }^{1}$, Ebtesam A. Yousef ${ }^{2}$, Mahmoud H. Hegab ${ }^{1^{*}}$ and \\ Nehad Khalifa ${ }^{1}$ \\ 1-National Institute of Oceanography and Fisheries (NIOF), Egypt. \\ 2- Department of Zoology, Faculty of Science, Sohag University, Egypt \\ *Corresponding author: Mahmoud H. Hegab (email: hegabmh@yahoo.com)
}

\section{ARTICLE INFO}

Article History:

Received:May 22, 2018

Accepted: June 28, 2018

Available online: July 2018

Keywords:

Ostracods

Heterocypris salina

Taxonomy

Morphological description

Molecular characters

\section{ABSTRACT}

Ostracods are microscopic crustaceans living in a wide variety of environments. They are very important as the key food item for fish and benthic macro-invertebrates and are used as bio-indicators for environmental changes and pollution. The identification and taxonomy of the Heterocypris species are so challenging issues because of their morphological plasticity that is often related to environmental factors. The studied species is recorded for the first time in Egypt. Therefore, Morphological evidences for the identification of this species were thoroughly recorded using the scanning electron and stereo microscopes. Furthermore, DNA barcoding was used to confirm the morphological identification. The morphological examination identified the species as Heterocypris salina, where it revealed an accurate description for its carapace, valves and appendages. However, few dissimilarities with the description of that species by other authors were noted. The sequencing of partial sequences of $28 \mathrm{~S}, 18 \mathrm{~S}$ rRNA genes confirmed the results of the morphological identification. New barcodes for 28S, 18S rRNA genes and cytochrome oxidase subunit 1 , COI gene, of $H$. salina were added to GenBank databases. Based on morphological and genetic evidences, this study adds new species to the biodiversity inventory of the aquatic environment of Egypt. Furthermore, COI sequence for Heterocypris salina has been submitted on the GenBank databases for the first time to be used as a marker for identification of such species in the future.

\section{INTRODUCTION}

Ostracods are tiny microscopic crustaceans, less than $3 \mathrm{~mm}$, with two-valve calcified carapace covering the whole body. The head region is completely separated from other parts (thorax and abdomen). However, the segmentation of the body is nearly disappeared. The head has most of the appendages (two pairs of antennae, a pair of mandibles and two pairs of maxillae). The thorax bears two pairs of appendages, but these are reduced to a single pair, or completely disappeared in many species. Their bodies end in two "rami", or projections (Barnes, 1982). Ostracods live in a wide variety of environments (Martens et al., 2008; Rasouli et al., 2014).

They are very important as the key food item for fish and benthic macro invertebrates (Chakrapani et al., 1996). They are used as bioindicators for 
environmental changes and pollution (Boomer and Attwood, 2007; Mohammed et al., 2014).

The diversity of the Ostracoda is not entirely documented, especially that of living ostracod, as it is incomplete and variable due to the different intensity of studies of different biogeographical regions (Rodriguez-Lazaro and Ruiz-Muñoz, 2012). The estimated total number of described living and fossil ostracod taxa at or below the species level is more than 65,000, including subspecies and synonymies (Ikeya et al., 2005). The estimated number of living species is 20,000, only about half of them have been described formally. Moreover, 2000 of these species are nonmarine with irregular geographical distribution (Martens and Horne, 2009). In Egypt, studies on fresh water Ostracoda still limited and needed to be intensified substantially (Yousef, 2010).

The criteria used to classify ostracods to 5 orders ,10 suborders and 16 superfamilies are based on morphological characteristics of soft and hard parts (Horne et al., 2002; Rodriguez-Lazaro and Ruiz-Muñoz, 2012). However, the taxonomy of the genus Heterocypris is difficult to be elucidated because of its wide distribution and morphological elasticity which is often related to environmental parameters (Benzie, 1984). Therefore, DNA- based identification is used to confirm the morphological identification since it provides rapid, clear and highly specific identification of all of the living organisms (Jagielski et al., 2013).

The analysis of a partial sequence of rRNA gene is considered an efficient molecular tool for species identification which can indorse the phenotype-based methods which sometimes produce refuted results (Jagielski et al., 2013). The small subunit, SSU rRNA is a common molecular marker frequently used in diversity research (Lindeque et al., 2013; Fonseca et al., 2014; Wu et al., 2015) and phylogenetic studies (Petrov et al., 2014; Zhang et al., 2015). The SSU rRNA are widely used for identification of species from different taxonomic groups from bacteria to higher animals (Jagielski et al., 2013; Wu et al., 2015). Yamaguchi and Endo (2003) used partial sequences of 18S rRNA gene in the identification of several ostracod species.

In addition, DNA barcoding using cytochrome oxidase subunit 1gene (COI), has been used as a method for rapid and accurate detection and identification of species (Hebert et al., 2003; Marshall, 2005; Hajibabaei et al., 2007). The divergence of the barcode region of COI gene in 150 crustacean families was studied by Costa et al. (2007) and confirmed its effectiveness in crustacean families' taxonomy. Therefore, the COI gene barcode region provides one of the best barcodes for the studied species identification.

Heterocypris is one of ostracods genera that is globally distributed. Many species of this genus have been described from different geographical regions where they have comparable size ranges and are very similar morphologically. Therefore, a detailed differential diagnosis is required to provide a better identification for newly described or re-described species of this genus (Victor and Fernando, 1980). Therefore, the present study represents an integrated morphological and molecular study to clearly identifying a newly recorded species of Ostracoda in Egypt, Heterocypris salina and to illustrate the similarities and dissimilarities (morphological re-description) of the morphological characteristics of this species with that described from different geographical points.

MATERIALS AND METHODS

\section{Collected specimens}


Samples of the investigated species were collected in June 2016 from Drawa Canal which is directly connected to the Damietta branch of River Nile near ElKanater Delta Barrage, Egypt. The sampling area is characterized by muddy bottom and the presence of dense higher plants on both banks. Samples were collected by filtering water around plants roots and stems with plankton net $55 \mu \mathrm{m}$ mesh size. In the laboratory, collected samples were cultured under the same environmental conditions during sample collection, where water salinity was $1 \%$, dissolved oxygen levels $\left(6.0 \mathrm{mg} \mathrm{l}^{-1}\right)$, water temperature $\left(24-25 \mathrm{C}^{\circ}\right)$ and $\mathrm{pH}(7.6$ to 8.1$)$, and was fed on Chlorella vulgaris.

\section{Microscopic Examination}

Forty-five of the cultured parthenogenetic ostracod females' specimens were identified under a stereo-microscope according to their valves and soft body parts. Specimens were separated and preserved in $70 \%$ ethyl-alcohol and dissected in a mixture of distilled water and glycerol (1:1) with fine tungsten needles. Dissected appendages of some specimens were mounted on slides in glycerol. Identification was done under higher magnifications $(10 \times 40$ or10 x 100) and the figures were drawn using a Camera Lucida. For Scanning Electron Microscope (SEM), individuals of ostracod species were fixed in a mixture of three volumes of $4 \%$ glutaraldehyde and one volume of $1 \%$ of osmium tetroxide. Then, they were dehydrated in a graded series of alcohol and coated by gold, and viewed under the electron microscope JEOL 5300 .

\section{Molecular Examination DNA extraction}

Samples used for molecular examination were preserved in Tris-EDTA buffer, $10 \mathrm{mM}$ Tris-HCL, $1 \mathrm{mM}$ EDTA, pH 8, in a clean sterile Eppendorf tube. DNA was extracted from the whole body of five samples using DNA extraction kit (Gene JET Genomic DNA Purification Kit Catalog no. K0721, Thermoscientific) according to the manufacture's protocol. However, a small tip was used in making fine mechanical grinding to help in lysing the hard external carapaces of the analysed samples. DNA extracted from all samples was quantified by Nano Drop spectrophotometer, and stored in $-20^{\circ} \mathrm{C}$ till used in PCR amplification.

\section{DNA Barcoding using COI gene:}

The COI mitochondrial gene was amplified using the following primer set described by (Folmer et al., 1994):

\section{LCO1490- CO1: GGTCAACAAATCATAAAGATATTGG}

HC02198- CO1: TAAACTTCAGGGTGACCAAAAAATCA

The amplification of COI mitochondrial gene was performed in a $25 \mu \mathrm{l}$ volume using BIOLINE master mix (2X My Taq Red Mix). The PCR mixture contained 12.5 $\mu 1$ master mix, $1 \mu \mathrm{l}$ DNA template (final concentration $20 \mathrm{mg}$ ) and $1 \mu \mathrm{l}$ of each primer (final concentration $0.25 \mu \mathrm{M}$ ). PCR was performed on a BIO-RAD PCR System (BIO-RAD, T100 Thermal Cycler, USA) with the thermal profile described by Folmer et al. (1994) as follows: an initial denaturation at $95^{\circ} \mathrm{C}$ for $4 \mathrm{~min}$., followed by 30 cycles: denaturation step at $94^{\circ} \mathrm{C}$ for $30 \mathrm{sec}$., annealing temperature $55{ }^{\circ} \mathrm{C}$ for $50 \mathrm{sec}$., and $90 \mathrm{sec}$. Extension at $72^{\circ} \mathrm{C}$, with a final extension of $7 \mathrm{~min}$ at $72^{\circ} \mathrm{C}$. PCR products were loaded to $2.5 \%$ agarose gel contains $2 \mu 1$ of Eth $\mathrm{Br}(100$ $\mathrm{mg} / \mathrm{ml}$ ), and electrophoresed.

\section{DNA Barcoding using 28S rRNA and 18S rRNA gene:}

The eukaryotic 28S rRNA gene was amplified using the following set of primers described by (Nunn et al., 1996): 


\section{S rRNA-F: 5'-GACCCGTCTTGAAACACGGA-3'}

\section{S rRNA-R: 5'-TCGGAAGGAACCAGCTACTA-3'}

Whereas, the eukaryotic 18S rRNA gene was amplified using the following set of primer described by (Lepere et al., 2011):

EuK-63F: 5'- ACGCTTGTCTCAAAGATTA-3',

Eukarya-1818R: 5'-ACGGAAACCTTGTTACGA-3'

All primers were manufactured using nucleotide synthesizer and purified through HPLC (Life Technology, England).

PCR amplification of a partial sequence of 18S rRNA and 28S rRNA genes was performed in a $25 \mu \mathrm{l}$ volume using BIOLINE master mix (2X My Taq Red Mix). The PCR mixture contained $12.5 \mu \mathrm{l}$ master mix, $1 \mu 1$ DNA template (final concentration $20 \mathrm{mg}$ ) and $1 \mu \mathrm{l}$ of each primer (final concentration $0.25 \mu \mathrm{M}$ ). PCR was performed using the same thermal cycler machine with the thermal profile: an initial denaturation at $95^{\circ} \mathrm{C}$ for $3 \mathrm{~min}$., followed by, 35 cycles: denaturation step at $95^{\circ} \mathrm{C}$ for $3 \mathrm{~min}$, annealing temperatures at $57^{\circ} \mathrm{C}$ for $50 \mathrm{sec}$. (for $18 \mathrm{~S}$ rRNA gene, as described by Nunn et al., 1996), and $55{ }^{\circ} \mathrm{C}$ for $50 \mathrm{sec}$. (for $28 \mathrm{~S}$ rRNA gene, as described by Lepere et al., 2011), and $1 \mathrm{~min}$ extension at $72^{\circ} \mathrm{C}$, with a final extension of $5 \mathrm{~min}$ at $72^{\circ} \mathrm{C}$. PCR products were loaded to $2.5 \%$ agarose gel contains $2 \mu \mathrm{l}$ of Eth $\mathrm{Br}(100$ $\mathrm{mg} / \mathrm{ml}$ ), and electrophoresed.

The produced singular bands with the expected band sizes were purified using the Gene JET Gel Extraction Kit (Catalog no. K0961, Thermo scientific). The purified PCR products of all samples were then undergone analyses by sequencing. Sequencing was done on the Applied Biosystems 3500 Genetic Analyzer Sequencer (Hitachi, Japan).

\section{Bioinformatics analyses}

The resulting row sequences were edited using BioEdit v 7.2.6, sequence alignment editor (www.mbio.ncsu.edu/BioEdit/page2.htm). The partial coding sequences for COI, 28s, and 18s rRNA genes of the studied species were compared in the GenBank database using BLAST algorithm to determine their similarity to the known sequences in the DNA database (https://www.ncbi.nlm.nih.gov/). Furthermore, most of Heterocypris salina and Heterocypris sp. 18S rRNA sequences in the DNA database (https://www.ncbi.nlm.nih.gov/) were retrieved from the GenBank database and aligned along with the 18S rRNA sequence of the studied species. This alignment was carried out using Clustal W software (Thompson et al., 1994) included in the MEGA6 software package (Tamura et al., 2013). The Pairwise genetic distances were calculated for all species based on 18S rRNA sequence using MEGA6 software. Phylogenetic tree was constructed using maximum likelihood Bootstrap method (provided as a phylogeny test in the MEGA software) and was performed using a number of 1000 bootstrap replications.

\section{Nucleotide sequence accession numbers}

The current 28S rRNA gene and 18S rRNA gene and COI gene sequences have been submitted in the GenBank/EMBL/DDBJ genetic databases. Accession numbers for $28 \mathrm{~S}$ rRNA, 18S rRNA gene and COI mitochondrial gene of the studied $H$. salina are listed in Table (1)

Table 1: Accession numbers of Heterocypris salina's 28S rRNA, 18S rRNA gene and COI mitochondrial gene, submitted to GenBank during current study.

\begin{tabular}{|l|l|}
\hline Barcodes of Heterocypri salina & Accession number \\
\hline 28S rRNA, Heterocypris salina & $\underline{\text { LC202975 }}$ \\
18S rRNA, Heterocypris salina & $\underline{\text { LC203079 }}$ \\
\hline COI mitochondrial gene, Heterocypris salina & $\underline{\text { LC319787 }}$ \\
\hline
\end{tabular}




\begin{tabular}{|l|l|}
\hline & $\underline{\text { LC324690 }}$ \\
\hline
\end{tabular}

\section{RESULTS}

\section{Morphological investigation}

Morphological investigation of the studied species showed that its carapace dimensions are: length (LV) 1.2-1.23mm $(n=56), \mathrm{H} / \mathrm{L}$ ratio $0.56-0.6(n=11)$.

\section{External morphological characteristics}

The dorsal view of the carapace is nearly oval in shape. The two valves are clearly unequal, where the left valve is larger than the right one and overlapping it. The maximum height is noticed approximately in the middle of the body (Figs. 1A1F). In lateral view, dorsal edge is distinctly arched while the posterior and anterior edges are broadly rounded (Figs. $1 \mathrm{G}$ and $1 \mathrm{H}$ ). The carapace surface is moderately inflated and has a few number of circular pore canals with long sensillae which increased at the margins (Fig. 1I).
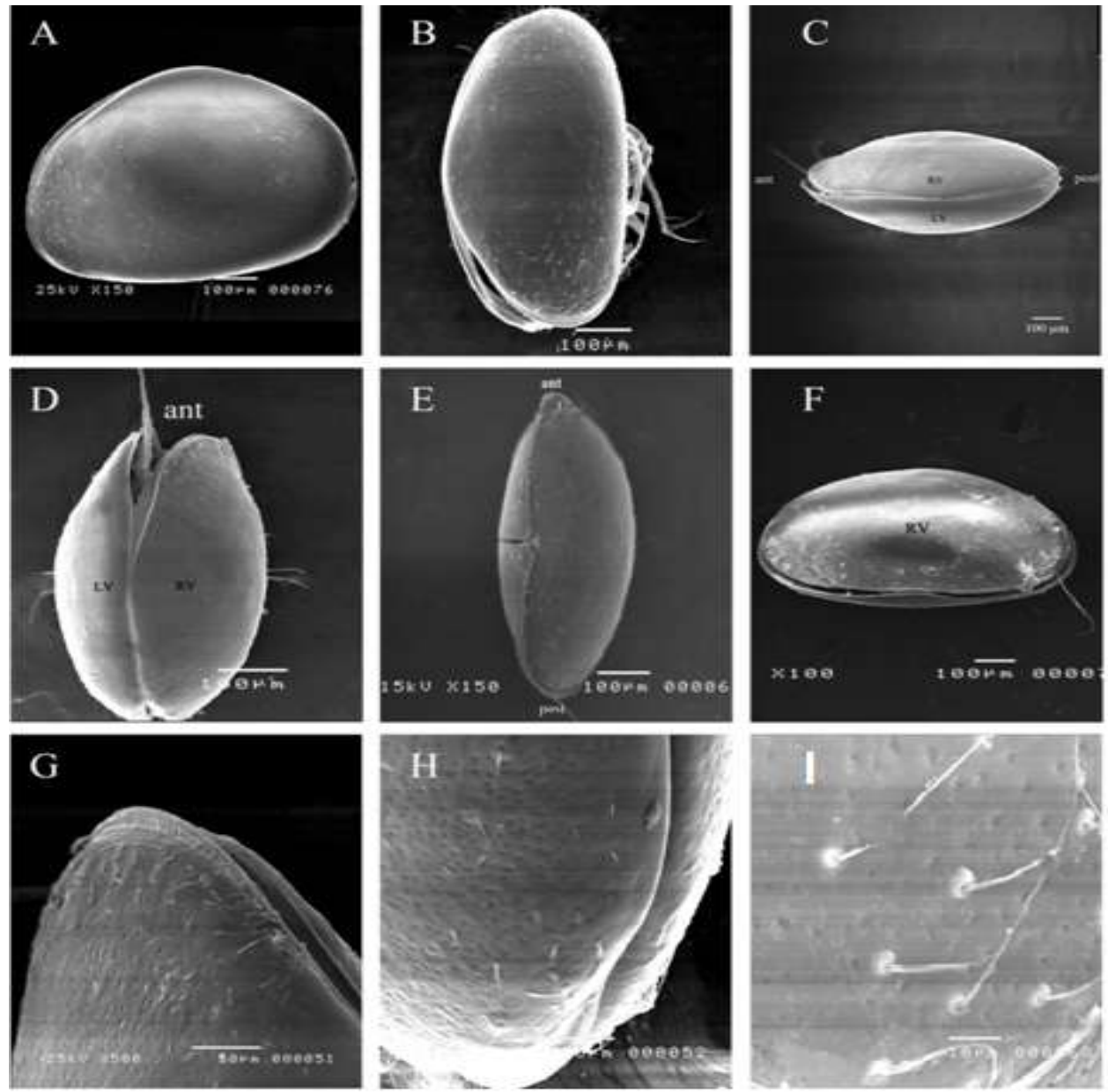

Fig. 1. Scanning Electron Microscope of female of Heterocypris salina (A,B): Lateral view of the carapace (C): Dorsal margin of carapace showing right and left valve (D): Dorsal margin of carapace showing attachment $(\mathrm{E})$ : Ventral margin of carapace $(\mathrm{F})$ : Lateral view of carapace showing right valve is smaller than the left valve $(G)$ : Enlarged of anterior portion of the carapace $(\mathrm{H})$ : Enlarged of posterior portion of the carapace $(\mathrm{I})$ : Pore canals with sensellae. $\mathrm{RV}=$ right valve, $L V=$ left valve, Ant $=$ anterior margin, Post $=$ posterior margin.

\section{Internal morphological characteristics}

The left valve is smooth with more thickness selvage at anterior edge than the posterior one, the vestibule is mild in widening and the inner lamella is narrow at all 
edge. The dorsal edge is distinctly arched, gradually descends until it is slightly concave at the postero-dorsal edge before the rounded edge emerges. The ventral edge is clearly convex in the middle and at the antero-ventral margin. The right valve (Figs. 2C and 2D) has about 25 tuberclesat the posterior edge, but the front edge is free of tubercles (Fig. 2E). The dorsal edge is arched and motivated till reaching the narrow anterior and posterior edge without transition. The carapace of the studied species has a dark-brown color pattern. A group of eight adductor muscle scars occurs in five (Fig. 2F).
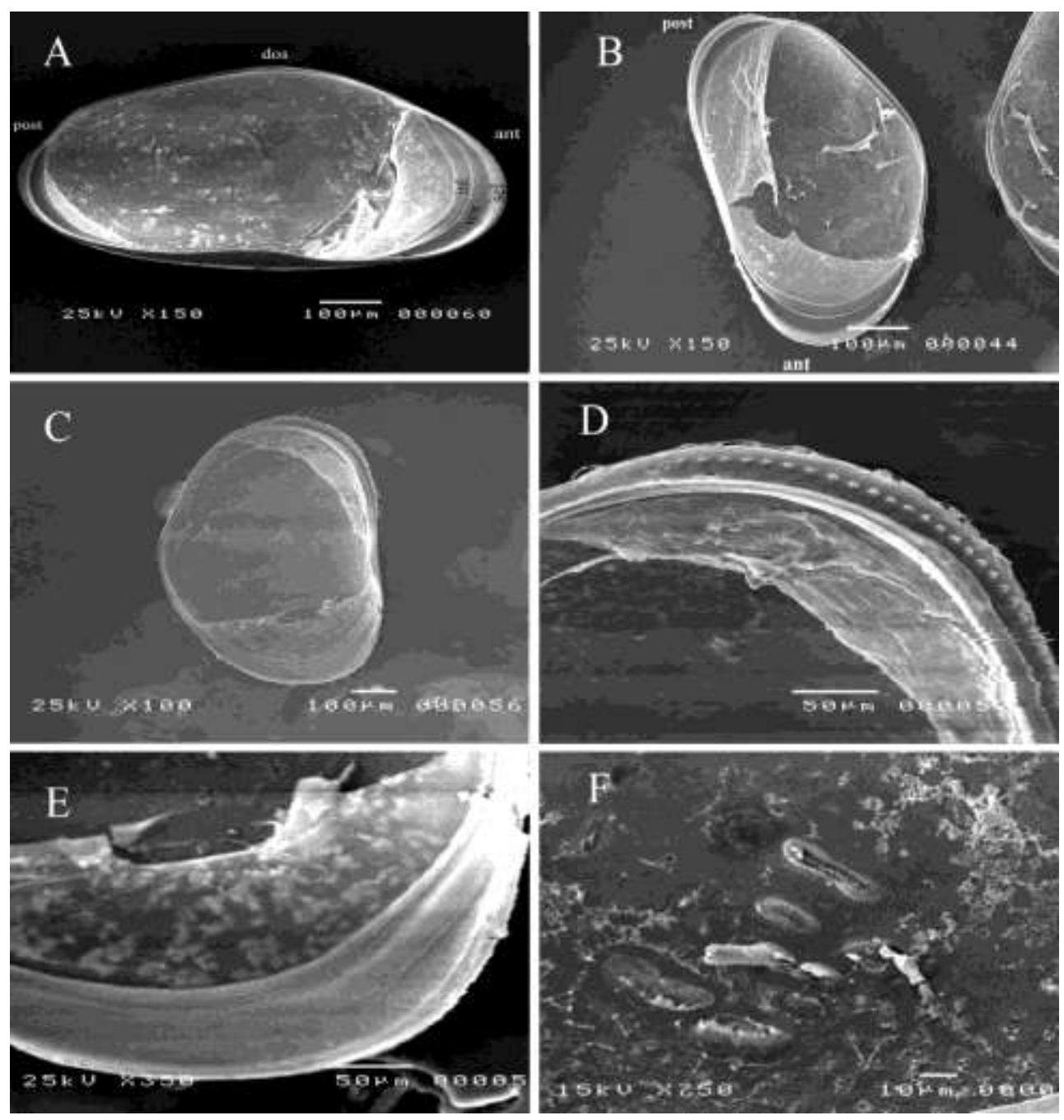

Fig. 2: Scanning Electron Microscope of Female of Heterocypris salina showing (A): Internal view of left valve (B): Hingement (C): Internal view of right valve (D): Enlarged of anterior portion of right valve $(\mathrm{E})$ : Enlarged of posterior portion of right valve $(\mathrm{F})$ : Muscle scars. inl = inner lamella, vest $=$ vestibule, sel $=$ selvage

First antenna (Figs. 3A, 3B and 4A), it consists of eight segments. The first two segments are united and together are forming a first large segment with quadrate base having one dorsal seta, and two unequal long ventral setae. The third segment has one dorsal pilose seta. The fourth segment elongated, with one ventro-distal long pilose seta and a short dorso-apical smooth seta. The fifth segment quadrate in shape, with two smooth, long dorso-apical setae and two unequal ventro-apical setae. The sixth segment is Semi-quadrate in shape, with two long, strong dorso-apical setae and one long ventro-apical seta. The seventh segment is elongated, with four strong, long 
apical setae and a short $\alpha$ seta ca. The terminal segment is slender bearing three unequal smooth setae.

Second antenna (Figs. 3C, 3D, 4B and 4C) consists of rectangular protopodite with a ventro-distal long pilose seta, exopodite of three unequal dorso-distal smooth setae and endopodite of four segments. The first endopodial segment with six smooth swimming setae reaching tip of terminal claws, one of them is short and not reaching middle of penultimate segment. Additionally, it bears two-segmented sensory club in the ventro-medium and a pilosedorso-distal seta. The second and third endopodite segments are fused with unclear suture, bearing two unequal dorso-central smooth setae, three dorso-distal smooth setae (z1, z2, z3), three long, slender pectinate claws (G1, G2, G3) and four unequal ventro-medium seta. The fourth endopoial segment with slender serrate claw (GM) and three smooth setae, one of them is slender pilose (Y).
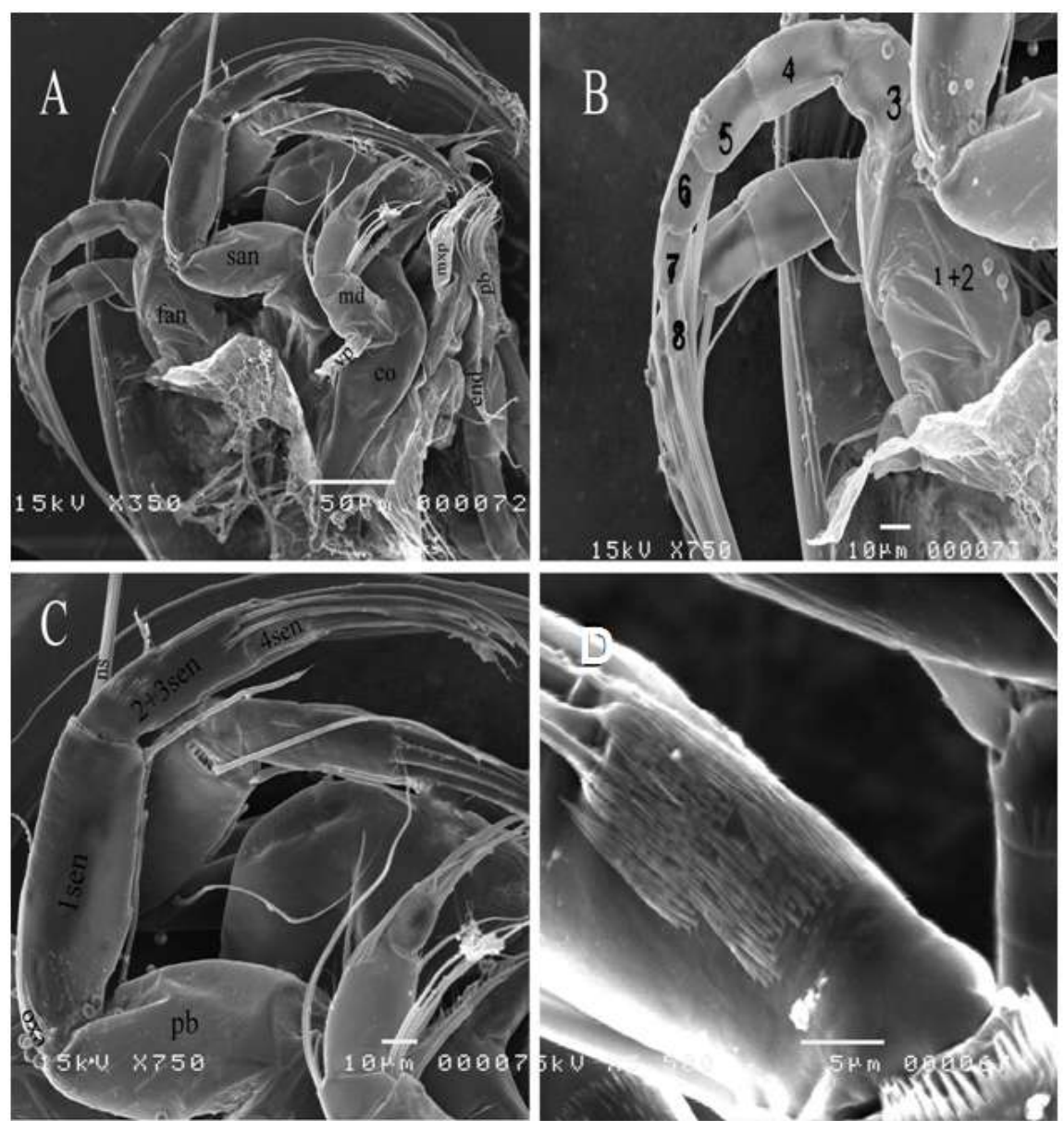

Fig. 3. Scanning Electron Microscope of Female of Heterocypris salina showing: (A): Appendages (B): First antenna (C): Second antenna (D): Enlarged of second antenna. fan = first antenna, san $=$ second antenna, $\mathrm{md}=$ mandibular palp, $\mathrm{vp}=$ vibratory plate, $\mathrm{co}=\mathrm{coxa}, \mathrm{mxp}=$ maxillary palp, end = endopodite, $\mathrm{ftl}=$ first thoracic leg, $1 \mathrm{sen}=$ first segment of endopodite, $2+3 \mathrm{sen}=$ second and third segments of endopodite, 4 sen = fouth segment of endopodite. 


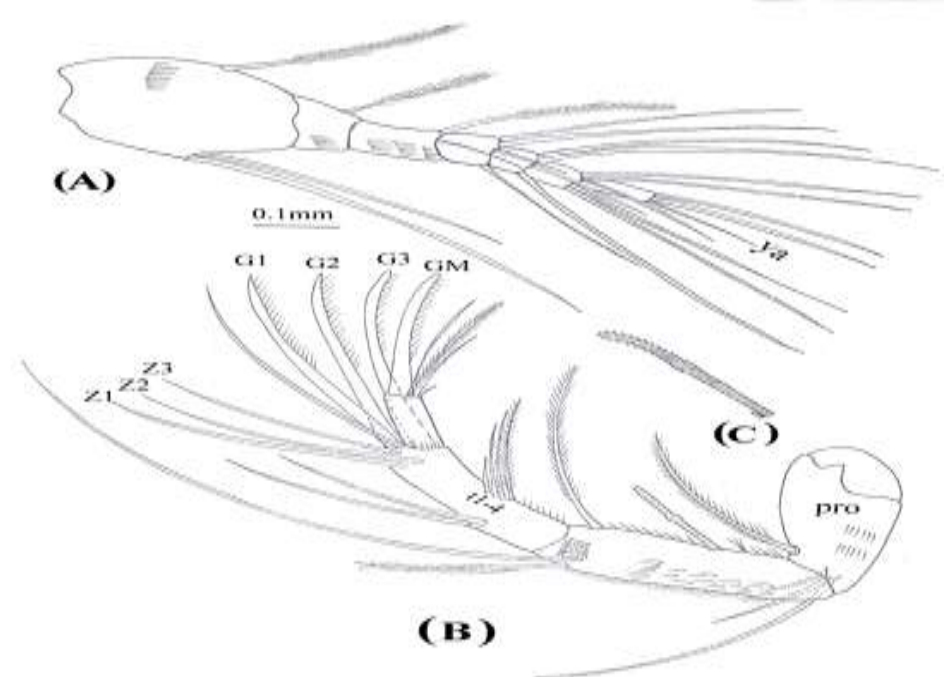

Fig. 4: Camera Lucida drawing of Heterocypris salina showing: (A): First antenna (B): Second antenna (C): Sensory club.

Mandible (coxa and mandibular palp) described in Figures 5A and 6, coxalenditeis with six blunt, short teeth intercalated with thin setae and two ventro-distal pilose, short setae. While the mandibular palp is strongly developed, composed of four segments, the first segment bears two pectinate setae, a long smooth slender seta, short smooth $\alpha$ seta and a fan of six long plumose branches. The second segment is wide and narrow bearing eight unequal slender setae and short pilose $\beta$ seta. The third rectangular segment has twelve unequal setae, five of them are pilose and carriesa stout Gamma seta which covered with many short settulae. The terminal segment is with three long, smooth claws and a short smooth site.

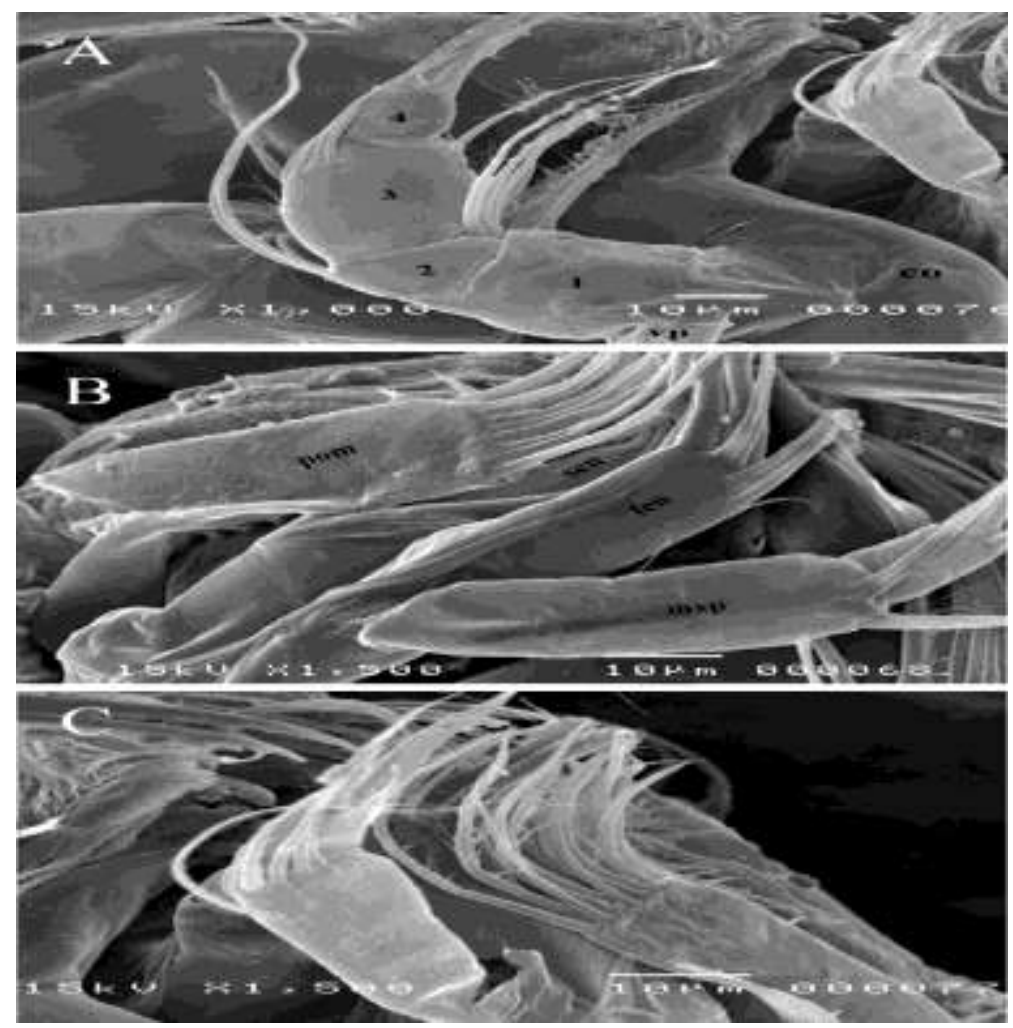

Fig. 5: Scanning Electron Microscope of Heterocypris salina showing (A): Mnadibular palp of mandible, $(\mathrm{B}, \mathrm{C})$ : Protopodite of maxilla, maxillary palp and two endites.co $=$ coxa , pom $=$ protopodite of maxilla, sen $=$ second endite, fen $=$ first endite, $\operatorname{mxp}=$ maxillary palp 


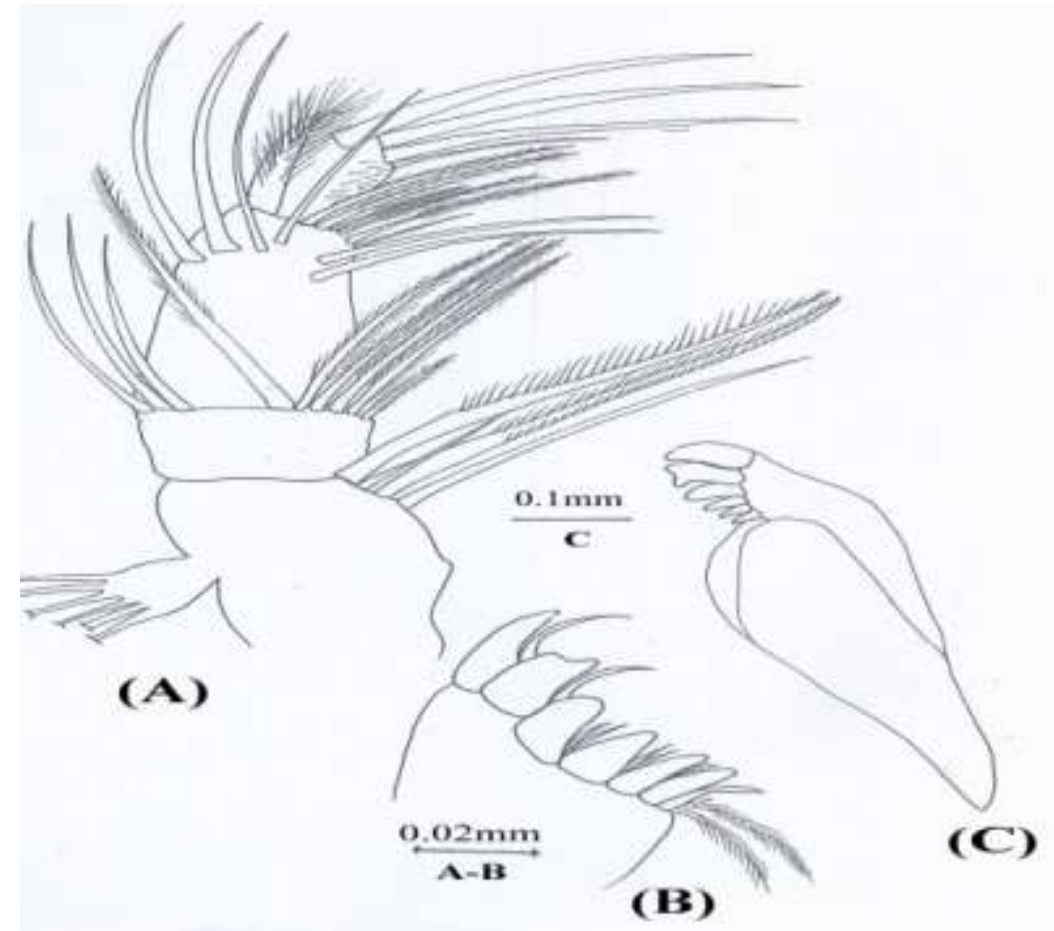

Fig. 6: Camera Lucida drawing of Heterocypris salina showing: (A): Mandibular palp (B): Enlarged of anterior portion of coxa (C): Coxa.

Maxillula (Figs. 5B, 5C and 7) consists of maxillular palp, three endites and branchial plate. Maxillular palp is double-segmented, the first segment is rectangular in shape and bears six smooth setae; one of them is long, while the second is with five smooth setae. The enditesincrease gradually in length towards the maxillular palp, the first endite with four smooth setae, blunt pilose seta and two biserrated setae. The second and third endites have seven and six setae, respectively. Branchial plate is with twenty plumose setae; three of them are long.

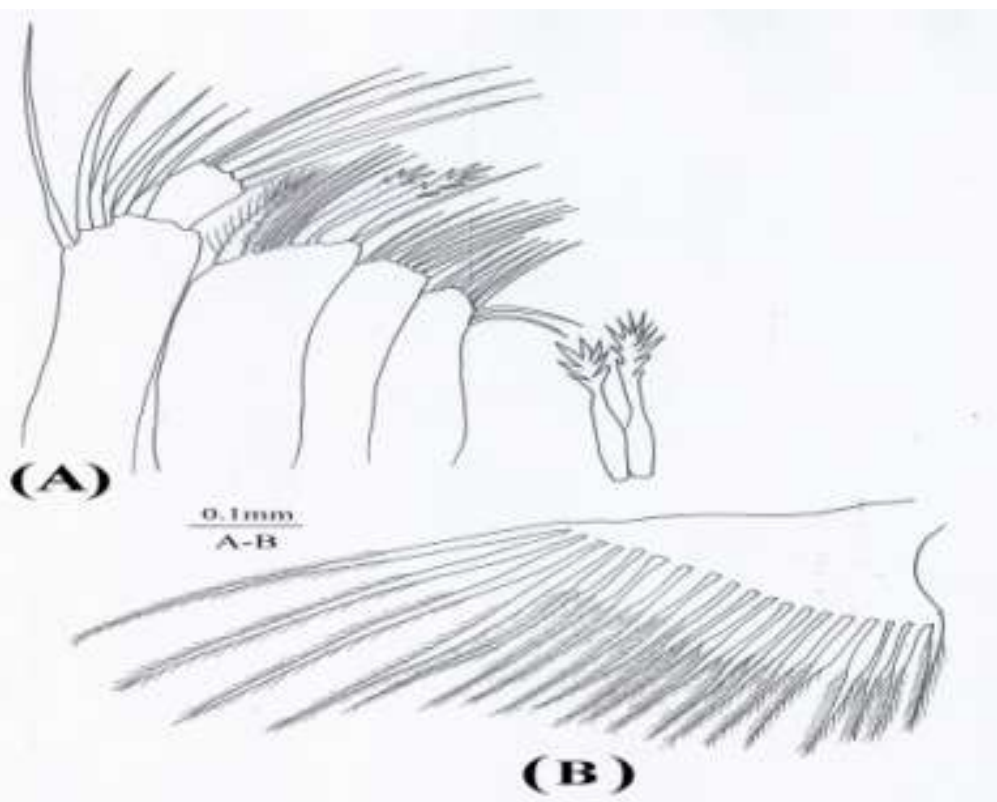

Fig. 7: Camera Lucida drawing of Heterocypris salina showing: (A): Maxillary palp and endites (B): Branchial plate. 
Maxilla (Fig.8B) has exopodite with six plumose rays, endopodite carries three unequal setae; one of them is long and pilose. Also, protopodite has twelve plumose setae and b and d pilose setae, while a seta is absent. Rake like organ (Fig.8A) with seven and eight teeth on right and left, respectively.

First thoracic leg (Figs. 8C, 9A and9B) (the walking leg) consists of four segments with some groups of minute setae. The second and third segments have a smooth seta at each one of them. The fourth segment is with a long bipectinate claw and three unequal smooth setae.

Second thoracic leg (Figs. 9C, 10A and 10B) (the cleaning leg) with three segments; the first one is long and has three smooth setae ( $11, \mathrm{~d} 2, \mathrm{dp})$, the second segment carries long pilosedorso-distal seta (e), while the terminal segment of second thoracic leg is with three finely, blunt pilose distal claws, smooth reflexed seta a little longer than the length of last podomere, a dorso-medium pilose seta (f) and a hook like pilose short seta (Terminal segment of L7 not cylindrical and not distinctly separated from the penultimate one, forming with the latter a "pincer organ" with a short clawlike seta).

Furca (uropodal ramus) (Figs. 9C, 10D and C) is nearly straight, slender with two groups of tiny setae at ventral margin. Claws $\mathrm{Ga}$ and $\mathrm{G}$ pare serrate and unequal in length. Sa and Sp setae are equal in length extending to the mid length of claws.

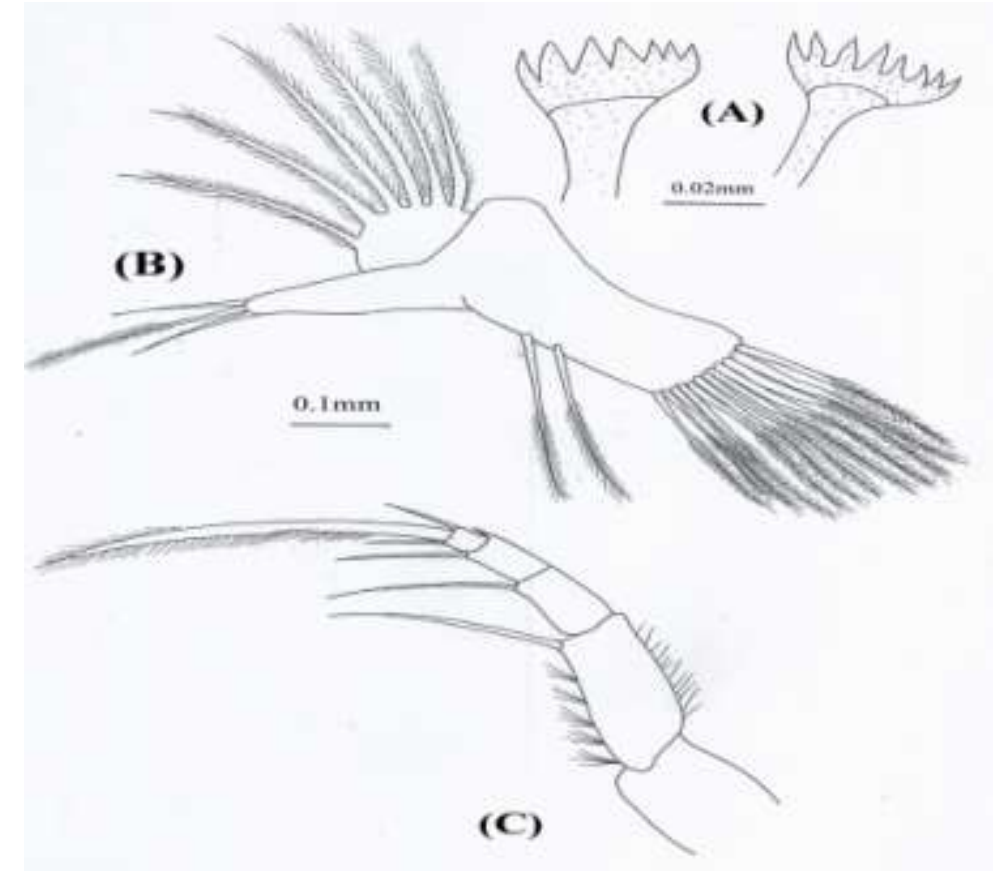

Fig. 8: Camera Lucida draws of Heterocypris salina showing: (A): Maxillula (B): Rake like organs, (C): First thoracic leg. 

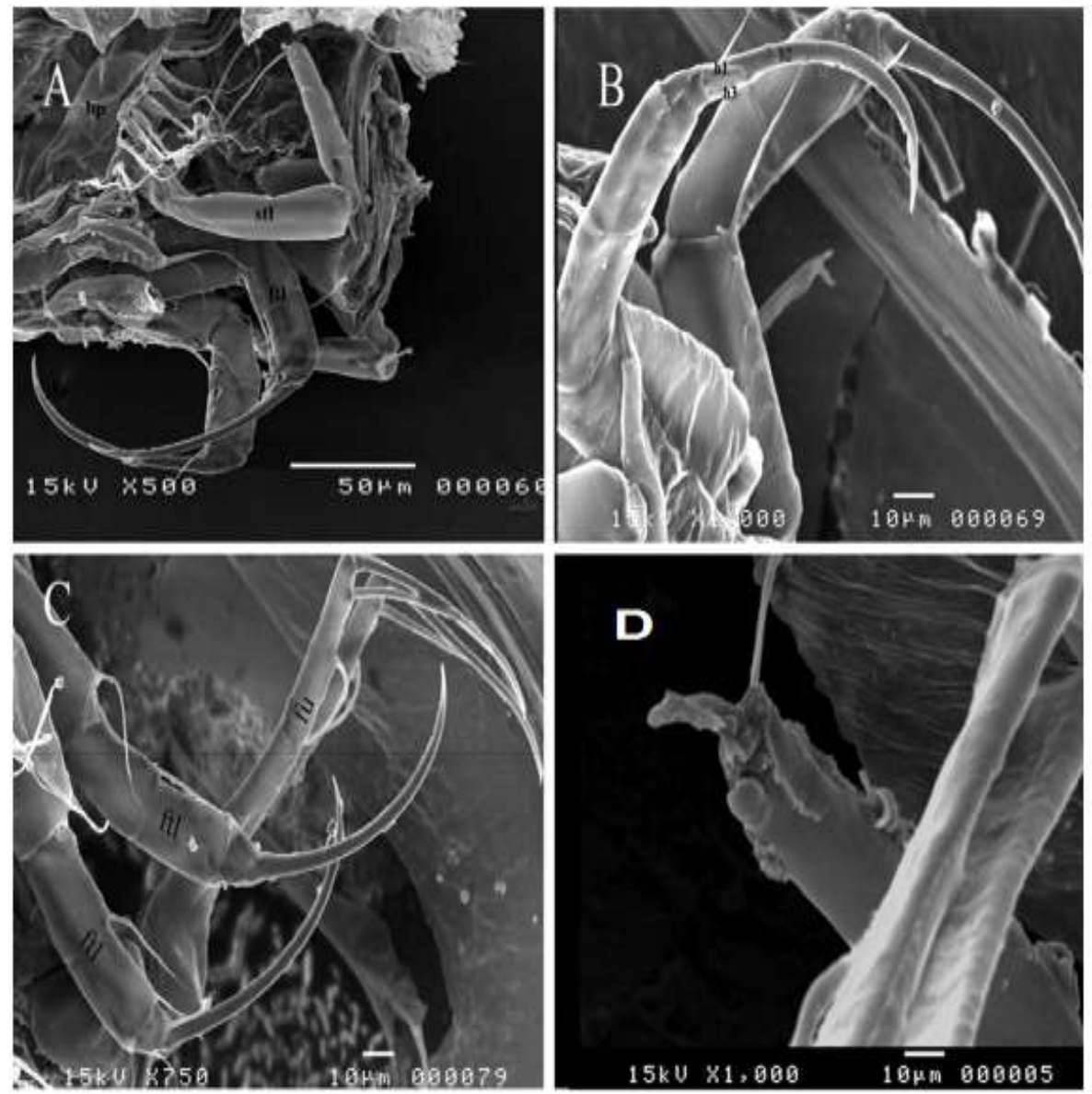

Fig. 9. Scanning Electron Microscope of Heterocypris salina showing: (A): First thoracic leg and second thoracic leg. (B): First thoracic leg: (C): Second thoracic leg and furca. (D): Terminal end of second thoracic leg.ftl = first thoracic leg, stl = second thoracic leg,

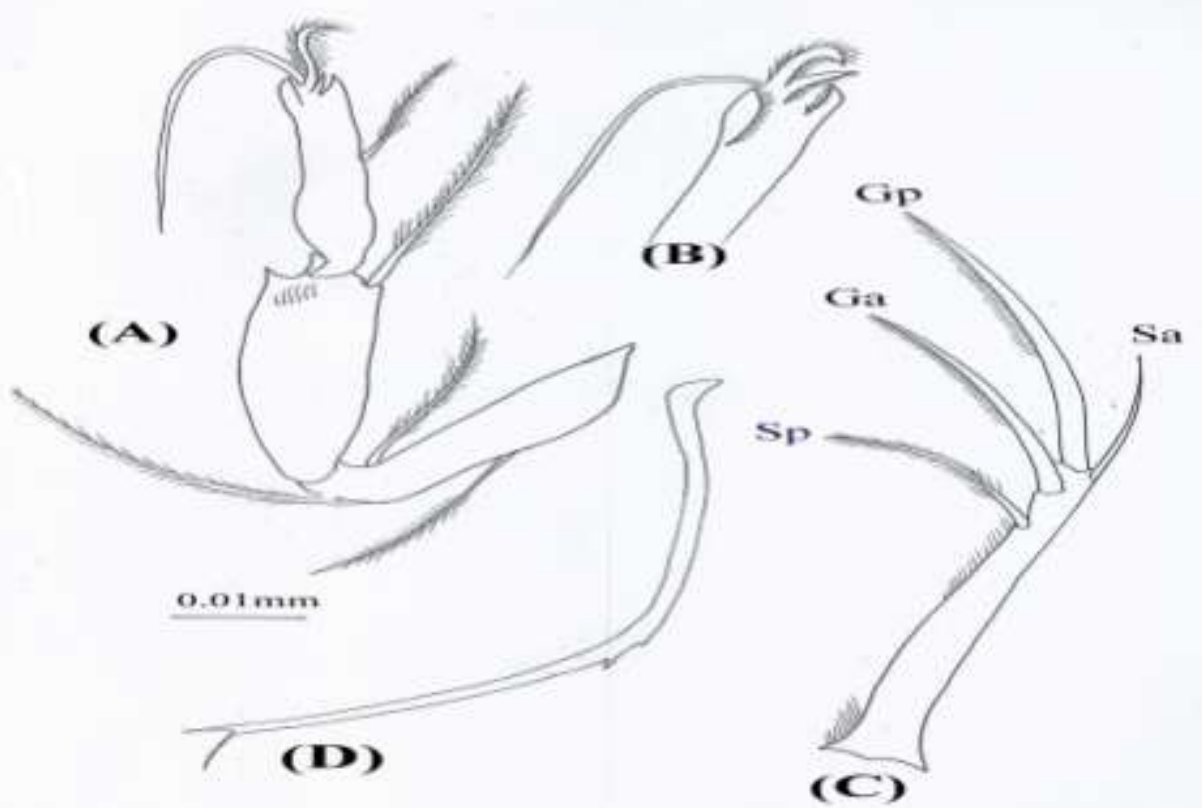

Fig. 10. Camera Lucida draws of Heterocypris salina showing: (A): Second thoracic leg (B): Enlarged of terminal end of the second thoracic leg (C): Furca (D): Furcal attachment. 


\section{Molecular analysis \\ BLAST comparisons}

All the tested samples showed positive PCR amplification of the COI mitochondrial genes, and eukaryotic $28 \mathrm{~S}$ and $18 \mathrm{~S}$ rRNA. The partial sequence of COI mitochondrial gene was primarily used as a variable marker for barcoding the studied species. The primers used for COI mitochondrial gene, LCO1490-CO1 and HC02198- CO1, amplified about 710 bp region of the COI mitochondrial gene. While performing BLAST, the aligned COI sequences did not provide a definite identification of the species, as there were no COI sequences for Heterocypris salina available on the GenBank database. Therefore, other markers were analyzed to genetically identify the studied species. $750 \mathrm{bp}$ of a partial eukaryotic $28 \mathrm{~S}$ rRNA gene was amplified. The alignment of the resulted sequences produced in a consensus length of 726 positions (base-pairs and gaps). The studied species showed 97\% similarity with Heterocypris sp. recorded in China (Accession number KX940932). A partial sequence of 18S rRNA gene was additionally amplified and sequenced to confirm the species identification. The 18S rRNA primer amplified about $1755 \mathrm{bp}$ region of the eukaryotic $18 \mathrm{~S}$ rRNA gene. The alignment of the resulted sequences obtained a consensus length of 1157 positions (base-pairs and gaps). The 18S rRNA sequences of the studied species showed $98 \%$ similarity with Chinese $H$. salina retrieved from GenBank database with the Accession numbers KX228779, KJ636055, which was supported by the microscopic examination.

$18 \mathrm{~S}$ rRNA-based pairwise genetic distances were calculated between the studied species and its counterpart references retrieved from GenBank database (Table 2), 18S rRNA-based pairwise distances for $H$. salina (the Egyptian species under study) ranged between 0.003 , in relation to its Chinese reference in the GenBank database (accession No. KX228779, KJ636055) to 0.011 in relation to Heterocypris sp., USA (accession no. L81944). The constructed phylogenetic tree based on 18S rRNA was shown in (Fig. 11) for the studied species. H. salina and its references in the GenBank. The tree was divided into two clusters with a single outlier, (Heterocypris sp.(L81944) from USA). The studied species, H. salina (from Egypt) was clustered with $H$. salina sequences from China (accession No. KX228779, KJ636055), whereas another Heterocypris sp. from China (accession No. DQ531761) and Heterocypris sp. from Korea (accession no. DQ531761) were paraphyletic.

Table 2: 18S rRNA based pairwise genetic distances among Heterocypris salina from Egypt (current study) and some references available in the GenBank database.

\begin{tabular}{|c|c|c|c|c|c|c|}
\hline & 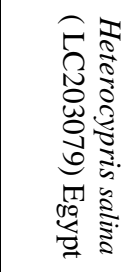 & 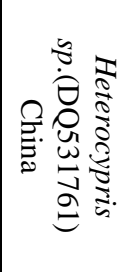 & 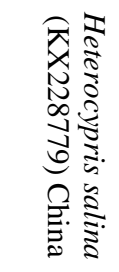 & 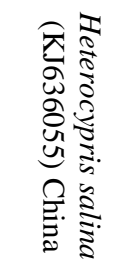 & 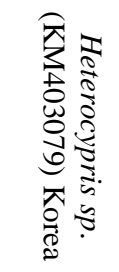 & 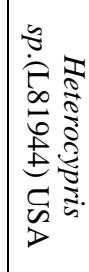 \\
\hline \multicolumn{7}{|l|}{ Heterocypris salina (LC203079) Egypt } \\
\hline Heterocypris sp. (DQ531761) China & 0.004 & & & & & \\
\hline Heterocypri salina (KX228779) China & 0.003 & 0.003 & & & & \\
\hline Heterocypris salina (KJ636055) China & 0.003 & 0.003 & 0.000 & & & \\
\hline Heterocypris sp. (KM403079) Korea & 0.004 & 0.004 & 0.005 & 0.005 & & \\
\hline Heterocypris sp. (L81944) USA & 0.011 & 0.011 & 0.012 & 0.012 & 0.009 & \\
\hline
\end{tabular}




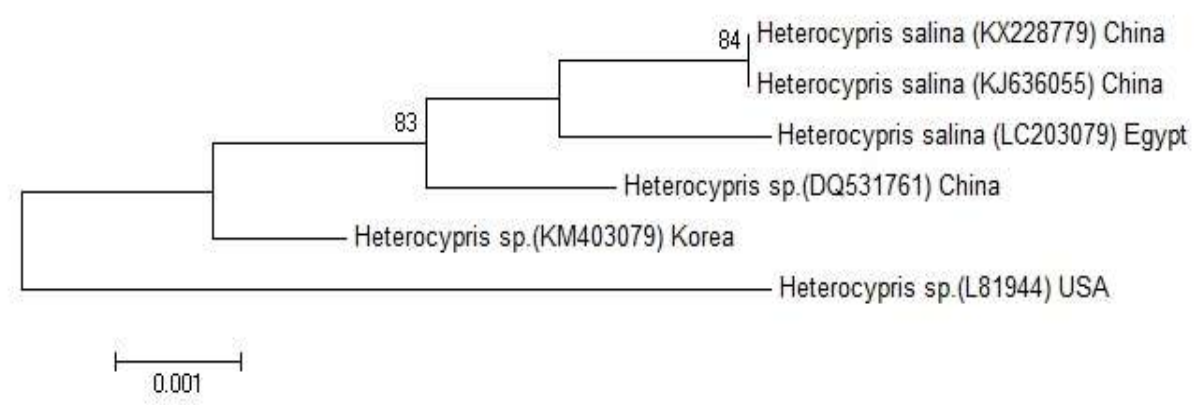

Fig.11. Maximum likelihood (ML) phylogenetic tree for the 18S rRNA gene sequences in the Egyptian $H$. salina and its references obtained from the GenBank database.

The sequences of COI in this study are the first COI sequence for $H$. salina to be submitted on the GenBank database. This sequence provided a novel barcode, which will help to identify $H$. salina species in the future.

According to the previous results, the identification of the studied species was confirmed by both molecular and microscopic examination to be Heterocypris salina that belongs to the Family: Cyprididae Baird, 1845 and Genus: Heterocypris Claus, 1893, according to the following Systematic position:

Phylum: Arthropoda

Sub-Phylum: Crustacea

Class: Ostracoda Latreille, 1802

Sub-Class: Podocopa Sars, 1866

Order: Podocopida Sars, 1866

Sub-Order: Cypridocopina Jones, 1901

Family: Cyprididae Baird, 1845

Genus: Heterocypris Claus, 1893

Species: Heterocypris salina (Brady, 1868)

\section{DISCUSSION}

The morphological examination identified the studied species as Heterocypris salina belonging to the genus Heterocypris, based on the diagnosis of such genus by Meisch (2000). He recorded unique morphological characteristics of that genus: lateral view of carapace is moderately thick, dorsal margin is usually distinctly arched; left valve is larger than right valve and overlapping it ventrally; right valve has no dorsal projection; furcais well developed and the anterior claw is longer than the half length of the ramus. All these characteristics were noticed in the studied species.

Regarding the carapace shape, the studied species had nearly an oval shaped carapace with the greatest height in the middle of body and the ventral margin was concave which was also described by Sars (1928); Meisch and Broodbakker (1993); Petkowski et al. (2000). However, Sars (1928); noticed that the greatest height was at $2 / 3$ of body length.

The carapace length of the studied specimens $(1.2-1.23 \mathrm{~mm})$ is nearly equal to that examined by Klie (1939) and Bronshtein (1947) (1.2 and $1.25 \mathrm{~mm}$, respectively). However, it is longer than that was examined by Matzke-Karaszand Witt (2005) (0.96- $1.1 \mathrm{~mm})$, In addition, the dorsal margin of the studied species was more arched 
than that recorded by Karanovic (2012). Moreover, the carapace shape of examined specimens is shorter in lateral view when compared to those illustrated by Meisch and Broodbakker (1993); Hollwedel andScharf (1988); Karanovic (2012) and resemble in dorsal view those recorded by Meisch and Broodbakker (1993); Hollwedel and Scarf (1988).

The presence of small tubercles on the edges of the right valve is an important characteristic of genus Heterocypris. Some authors recorded the presence of these tubercles in both the anterior and the posterior margins of the right valve of $\mathrm{H}$. salina (Petkowski et al., 2000; Sars, 1928; Meisch and Broodbakker, 1993). However, the examination of the studied species recorded the presence of small 25 tubercles in the posterior edge of right valve only, which is agree with the observation of Bergue, et al. (2015).

On the other hand, the morphological features of soft body appendages of the studied species are similar to that of adult of $H$. salina as described by Kubanç et al. (2007), except two differences:

1- The studied species has one ventral-distal long pilose seta in protopodite of second antenna while H. salina described by Kubanç et al. (2007), has three unequal setae.

2- The first endite of Maxillula has blunt pilose, as well as four smooth setae and two biserrated setae while blunt pilose is disappeared in $H$. salina described by Kubanç et al.(2007).

Generally, the results of morphological study, when compared with previous studies (Meisch and Broodbakker 1993; Hollwedel and Scharf 1988; Petkowski et al., 2000; Meisch 2000; Kubanç et al., 2007; Karanovic 2012; Bergue et al. 2015) implied that the studied species is $H$. salina, inspite of limited differences. These differences could be explained on the bases of that the genus Heterocypris is characterized by morphological plasticity which often is related to environmental factors (Benzie, 1984). Moreover, reproductive isolation and restricted gene flow, can lead to genetic and phenotypic differences among isolated populations that may result in the establishment of new genetic and morphological clusters (Barraclough and Nee, 2001).

The morphological identification of the studied species is confirmed by DNA barcoding using 28S, 18S rRNA. The identification of ostracod species using $18 \mathrm{~S}$ rRNA gene analysis was quite common, Yamaguchi and Endo (2003) used the sequences for the $18 \mathrm{~S}$ rRNA of 17 ostracod species identification, those species represented 4 orders and 12 superfamilies of Ostracoda. Several taxonomic studies have also used 18S rRNA gene as a good molecular marker for studying the biodiversity of specific groups, such as Subclass Copepoda, Wu et al. (2015). Likewise, the use of both 28S rRNA sequence and 18S rRNA in this study was a good marker for the barcoding and the proper identification of the studied species.

Cytochrome oxidase 1, COI is a powerful variable marker that can be more suitable for distinguishing closely related species (Hajibabaei et al., 2007). Crustacean COI barcode region exhibited the highest species-level divergence rate among all animal groups Costa et al. (2007).

A major drawback that was faced during this study was the rare counterpart reference 18S rRNA gene sequences on the GenBank database and the complete absence of COI sequences for Heterocypris salina. In this study, both 28S rRNA and $18 \mathrm{~S}$ rRNA sequence were good markers for the barcoding and confirmed the morphological identification of the species. 
On the other hand, before the present study, no COI sequence data for Heterocypris salina was found in the GenBank/EMBL/DDBJ databases and the three Egyptian COI sequences of Heterocypris salina resulted from this study are the first submitted sequences on the GeneBank genetic databases. These sequences will provide barcodes for identifying Heterocypris salina species in the future.

It was obvious that the available sequence data on the GenBank database for Heterocypris salina was limited for 28S rRNA genes and nothing for COI gene. Therefore, the phylogenetic tree for $H$. salina sample from Egypt and its counterpart references from other countries was constructed based on 18S rRNA gene sequence since there is very limited data for $H$. salina rRNA gene on the GenBank database. Values for the pairwise genetic distances between $H$. salina from Egypt and its references were low reflecting the decreased genetic distances between them. However, the Heterocypris sp. (L81944) recorded in the USA is genetically distant from other $H$. salina references.

\section{CONCLUSION}

The present study combined two techniques to confirm the identification of anostracod species Heterocypris salina (Brady, 1868) which is recorded for the first time in the fresh water environment of Egypt. The study used a phenotype-based analysis method (microscopic examination) parallel to DNA-based method to produce an accurate identification and re-description of the studied species. The electron microscope analysis revealed a complete description for carapace, valves and the appendages of female individuals of $H$. salina. The sequencing of partial sequences of 28, $18 \mathrm{~S}$ rRNA was able to clearly identify the studied species as $H$. salina and was proven to be a good marker for species identification. Novel barcodes of COI sequences for $H$. salina were submitted to GenBank genetic database to be used as identification marker for such species in the future. Based on morphological and genetic evidences, this study adds new species to the biodiversity inventory of the aquatic environment of Egypt. Furthermore, it will help invertebrates' scientists to clearly identify one of the ostracod species, Heterocypris salina. However, much work is still needed for the identification and barcoding of other ostracod species globally.

\section{REFERENCES}

Barnes, R. D. (1982). Invertebrate Zoology. Philadelphia, PA: Holt-Saunders International (pp. 389-430). ISBN 0-03-056747-5.

Barraclough, T. G. and Nee, S. (2001). Phylogenetics and speciation. Trends Ecol. Evol., 16 (7): 391-399.

Benzie, J. A. (1984). Small scale diurnal migration by Heterocypris incongruens (Ramdohr 1808) (Ostracoda: Cyprididae) in a temporary pool in Ghana, West Africa. J. Crust. Biol., 4: 63-65.

Bergue, C. T.; Maranhao, M. D. S. A. and Fauth, G. (2015). Paleolimnological inferences based on Oligocene ostracods (Crustacea: Ostracoda) from Tremembé Formation, Southeast Brazil. Anais da AcademiaBrasileira de Ciências, 87 (3): 1531-1544. 
Boomer, L. and Attwood, F. (2007). Ostracods as freshwater pollution indicators: A case study from the Ouseburn, a polluted urban catchment (Tyneside, NE England). J. Micro, palaeontol., 26 (2):117- 125.

Bronshtein, Z. S. (1947). Ostracoda Presnyk Mod. Fauna S.S.S.R., Rakoobrazne, Tom 2, Vyp. 1. Akademiya Nauk S.S.S.R., Moscow, (English translation: (1988). Freshwater Ostracoda. Fauna of the U.S.S.R., Crustacea, Vol. 2, No.7. Amerind. Publishing Co. Pvt. Ltd., New Delhi, India for the US Department of the Interior.

Chakrapani, B. K.; Krishna, M. B. and Srinivasa, T. S. (1996). A Report on the water quality, plankton and bird populations of the lakes in and around Bangalore and Maddur, Karnataka, India. Department of Ecology and Environment, Government of Karnataka. http://wgbis.ces.iisc.ernet.in/energy/water/paper/Tr-115/ref.htm.

Costa, F. O.; DeWaard, J. R.; Boutillier, J.; Ratnasingham, S.; Dooh, R. T.; Hajibabaei, M. and Hebert, P. D. (2007). Biological identifications through DNA barcodes: the case of the Crustacea. Canad. J. Fish. Aquat. Sci., 64 (2): 272-295.

Folmer, O.; Black, M.; Hoeh, W.; Lutz, R. and Vrijenhoek, R. (1994). DNA primers for amplification of mitochondrial cytochrome c oxidase subunit I from diverse metazoan invertebrates. Mol. Mar. boil. biotech., 3 (5): 294-299.

Fonseca, V. G.; Carvalho, G. R.; Nichols, B.; Quince, C.; Johnson, H. F. and Neill, S. P. (2014). Metagenetic analysis of patterns of distribution and diversity of marine meiobenthic eukaryotes. Glob. Ecol. Biogeogr. Lett., 23 (11): 12931302.

Hajibabaei, M.; Singer, G. A.; Clare, E. L. and Hebert, P. D. (2007). Design and applicability of DNA arrays and DNA barcodes in biodiversity monitoring. BMC Biol., 5 (1), 24.

Hebert, P. D.; Cywinska, A.; Ball, S. L. and DeWaard, J. R. (2003). Biological identifications through DNA barcodes. Proc. Roy. Soc. B-Biol. Sci., 270 (1512): 313-321.

Hollwedel, W. and Scharf, B. W. (1988). Süßwassercladoceren und -ostracoden auf den niedersächsischen Nordseeinse ln Mellum und Memmert. Drosera, 88: 341369.

Horne, D. J.; Cohen, A. and Martens, K. (2002). Taxonomy, morphology and biology of Quaternary and living Ostracoda. In: Holmes, J.A. \& Chivas, A.R. (Eds), The Ostracoda: Applications in Quaternary Research, AGU Geophysical Monograph, 131: 5-36.

Ikeya, N.; Tsukagoshi, A. and Horne, D. J. (2005). The phylogeny, fossil record and ecological diversity of ostracod crustaceans. Hydrobiologia, 538: vii-xiii.

Jagielski, T.; Kosim, K.; Skóra, M and Barbara Macura, A. (2013). Identification of Scopulariopsis species by Partial 28S rRNA Gene Sequence Analysis. Polish. J. Microbiol., 62 (3): 303-306.

Karanovic, I. (2012). Recent Freshwater Ostracods of the World. Crustacea, Ostracoda, Podocopida. Springer: Berlin, Germany, 608p.

Klie, W. (1939). Ostracodenausdem Kenia-gebiet, vornehmlich von dessen Hochgebirgen. Int. Revue ges. Hydrobiol. Hydrogr., 39: 99-161.

Kubanç, N.; Özulug, O. and Kubanç, C. (2007). The ontogeny of appendages of Heterocypris salina (Brady, 1868) Ostracoda (Crustacea). Hydrobiologia, 585: 255-272. 
Lepere, C.; Demura, M.; Kawachi, M.; Romac, S. and Probert, I. (2011). Whole genome amplification (WGA) of marine photosynthetic eukaryote populations. FEMS. Microbiol. Ecol., 76: 513-523

Lindeque, P. K.; Parry, H. E., Harmer, R. A.; Somerfield, P. J. and Atkinson, A. (2013). Next Generation Sequencing Reveals the Hidden Diversity of Zooplankton Assemblages. PLoS one, 8 (11): e81327.

Marshall, E. (2005). Taxonomy. Will DNA barcodes breathe life into classification?. Science, 307 (5712): 1037

Martens, K. and Horne, D. J. (2009).Ostracoda. In: Likens, G.E. (Ed.), Encyclopedia of Inland Wat., 2: 405- 414.

Martens, K.; Söcn, I.; Meisch, C. and Horne, D. J. (2008). Global biodiversity of nonmarine Ostracoda (Crustacea). Hydrobiologia, 595: 185-193.

Matzke-Karasz, R. and Witt, W. (2005). Ostracods of the Paratethyan Neogene Kilıç and Yalakdere Formations near Yalova (İzmit Province, Turkey). Zitteliana, 45: 111-129.

Meisch, C. (2000). Freshwater Ostracoda of Western and Central Europe. In: J. Schwoerbel \& P. Zwick (eds), Süßwasser fauna von Mitteleuropa 8/3. Spektrum Akademischer Verlag, Heidelberg, 522pp.

Meisch, C. and Broodbakker, N. W. (1993). Freshwater Ostracoda (Crustacea) collected by Prof. J. H. Stock on the Canary and Cape Verde islands. With an annotated checklist of the freshwater Ostracoda of the Azores, Madeira, the Canary, the Selvagens and Cape Verde islands. Travauxscientifiques du Musée national d'histoirenaturelle de Luxembourg, 19: 3-47.

Mohammed, M. A.; Keyser, D.; Al-Wosabi, M. A.; Al-Khirbash, B. and Al-Qadassi, W. M. (2014). Taxonomy and distribution of fresh water Ostracoda from Socotra Island, Yemen. Revue de micropaléontologie., 57 (1): 23-33.

Nunn, G. B.; Theisen, B. F.; Christensen, B. and Arctander, P. (1996). Simplicitycorrelated size growth of the nuclear 28S ribosomal RNA D3 expansion segment in the crustacean order Isopoda. J. Mol. Evol., 42: 211-223.

Petkowski, T.; Scharf, B. and Keyser, D. (2000). New and little known ostracods of the genus Heterocypris (Crustacea, Ostracoda) from the Balkan Peninsula. Limnologica, 30: 45- 57.

Petrov, A. S.; Bernier, C. R.; Gulen, B. Waterbury, C. C.; Hershkovits, E. and Hsiao, C. L. (2014). Secondary Structures of rRNAs from All Three Domains of Life. PLoS one, 5: 9 (2).

Rasouli, K.; Pomeroy, J. W.; Janowicz, J. R.; Carey, S. K. and Williams, T. J. (2014). Hydrological sensitivity of a northern mountain basin to climate change. Hydrological Proc., 28 (14): 4191-4208.

Rodriguez-Lazaro, J. and Ruiz-Muñoz, F. (2012). A general introduction to ostracods: morphology, distribution, fossil record and applications. In Developments in Quaternary Sciences, 17: 1-14, Elsevier.

Sars, G.O. (1928). An account of the Crustacea of Norway with short descriptions and figures of all the species. 9 (Ostracoda) (parts 15/16): 241-277. Bergen: Bergen Museum.

Tamura, K.; Stecher, G.; Peterson, D.; Filipski, A. and Kumar, S. (2013). MEGA6: Molecular Evolutionary Genetics Analysis version 6.0. Mol. Boil. Evol., 30: 2725-2729.

Thompson, J. D.; Higgins, D. G. and Gibson, T. J. (1994). CLUSTAL W: improving the sensitivity of progressive multiple sequence alignment through sequence 
weighting, position-specific gap penalties and weight matrix choice. Nucleic Acids Res., 22 (22), 4673-4680.

Victor, R. and Fernando, C. H. (1980). On Heterocyprismakua (Tressler) 1937, a freshwater ostracod (Crustacea: Ostracoda) from the Hawaiian Islands, with notes on the other species of the genus. Can. J. Zool., 58 (7): 1288-1297.

Wu, S.; Xiong, J. and Yu, Y. (2015). Taxonomic Resolutions Based on 18S rRNA Genes: A Case Study of Subclass Copepoda. PLoS one. 10(6): e0131498.

Yamaguchi, S. and Endo, K. (2003). Molecular phylogeny of Ostracoda (Crustacea) inferred from 18S ribosomal DNA sequences: implication for its origin and diversification. Mar. Biol., 143: 23-38.

Yousef, E. A. (2010). Taxonomy and description of the female Candonocyprisnovaezelandiae (Baird, 1843) (Crustacea: Ostracoda) from River Nile, Sohag Governorate, Egypt. Egypt. Acad. J. Biol. Sci, 2 (2): 61- 69.

Zhang, G. Q.; Li, M. H.; Su, Y. Y.; Chen, L. J.; Lan, S. R. and Liu, Z. J. (2015). A new myco-heterotrophic genus, Yunorchis, and molecular phylogenetic relationships of the tribe Calypsoeae (Epidendroideae, Orchidaceae) inferred from plastid and nuclear DNA sequences. PLoS one, 10: e0123382.

\section{ARABIC SUMMARY}

\section{اعادة التوصيف المورفولوجي ودراسة خصائص التركيب الجزيئي للهيتيروسيبروس سالينا Heterocypris salina (Class: Ostracoda)}

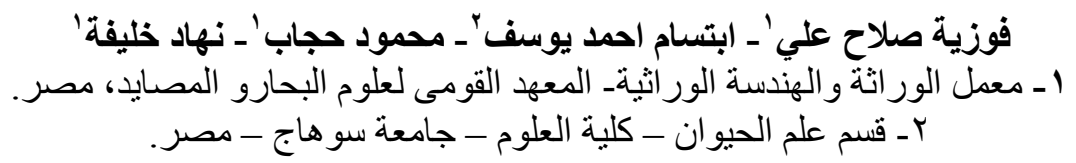

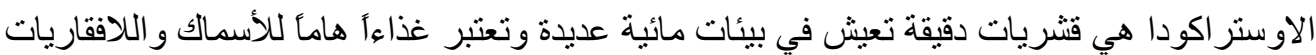

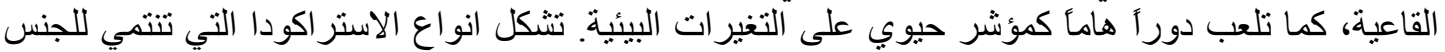
Heterocypris

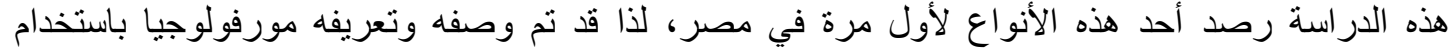

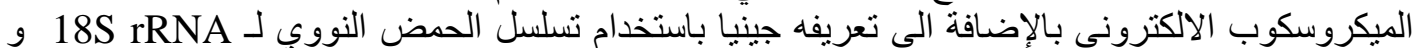
28S rRNA

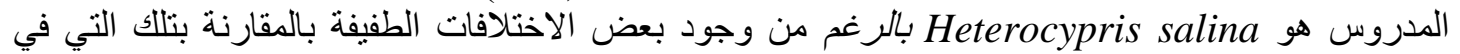

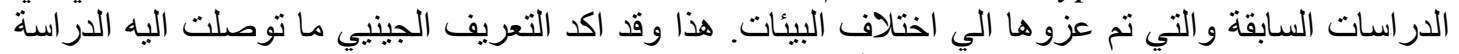

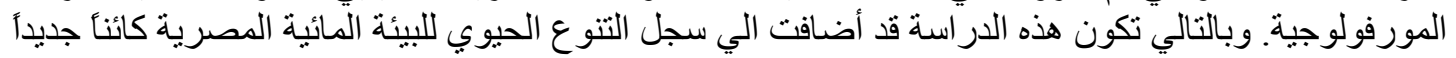

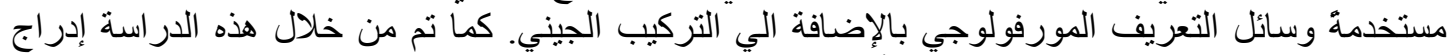

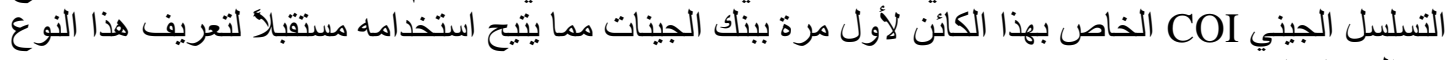
من اللافقاريات. 